\title{
The hepatoprotective effect of Cheral as anti-oxidant and anti- inflammation on mice (Mus musculus) with breast cancer
}

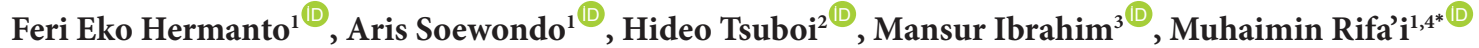 \\ ${ }^{1}$ Biology Department, Faculty of Mathematics and Natural Sciences, Brawijaya University, Jl. Veteran Malang 65145, East Java, Indonesia \\ ${ }^{2}$ Department of Immunology, Nagoya University Graduate School of Medicine, 65 Tsurumai-cho, Showa-ku, Nagoya 466-8550, Japan \\ ${ }^{3}$ Pancasakti University, Makasar 90132, South Sulawesi, Indonesia \\ ${ }^{4}$ Biosystem Study Center, Brawijaya University, Jl. Veteran Malang 65145, East Java, Indonesia
}

\section{A R T I C L E I N F O}

Article Type:

Original Article

Article History:

Received: 23 October 2019

Accepted: 31 December 2019

Keywords:

Breast cancer

Cheral

Liver oxidative stress

Proinflammatory cytokines

\begin{abstract}
A B S T R A C T
Introduction: Recent studies have reported that breast cancer may affect the physiology of other organs, including oxidative stress in the liver. On the other hand, some agents such as white turmeric (Curcuma longa) and Meniran (Phyllanthus niruri) seem to maintain redox stability and immunomodulation. Both of them are combined into Cheral potion. This study was aimed to investigate the Cheral efficacy in modulating oxidative stress based on Nuclear factor erythroid 2-related factor 2 (Nrf2), HEME OXIGenase (HO), and superoxide dismutase (SOD) levels as well as pro-inflammatory cytokines under breast cancer condition in vivo.

Methods: Nrf2, HO, and SOD from hepatocytes, and tumor necrosis factor- $\alpha$ (TNF- $\alpha$ ) and interferon- $\gamma$ (IFN- $\gamma$ ) from splenocytes were measured by flow cytometry after 14 days of Cheral administration.

Results: The results showed that mice model for breast cancer underwent oxidative stress denoted by high levels of HO, and SOD accompanied by increased levels of TNF- $\alpha$ and IFN $-\gamma$ in the cancer group compared to normal healthy group $(P<0.05)$. In contrast, Cheral treatment was able to modulate redox balance by declining levels of HO, SOD, TNF- $\alpha$, and IFN- $\gamma$, but not Nrf2, compared to cancer group $(P<0.05)$.

Conclusion: The results showed that breast cancer could alter the host's physiology, including liver oxidative stress. The levels of TNF- $\alpha$ and IFN- $\gamma$ might contribute to regulation of redox balance in the liver. However, Cheral has potency as an alternative therapeutic agent to reduce oxidative stress in the liver under breast cancer condition.
\end{abstract}

Implication for health policy/practice/research/medical education:

Cheral showed to be a good therapeutic alternative to prevent oxidative stress and inflammation during breast cancer progression. Hence, it might be beneficial in patients with these conditions, especially the ones with breast cancer.

Please cite this paper as: Hermanto FE, Soewondo A, Tsuboi H, Ibrahim M, Rifa'i M. The hepatoprotective effect of Cheral as anti-oxidant and anti-inflammation on mice (Mus musculus) with breast cancer. J Herbmed Pharmacol. 2020;9(2):153-160. doi: 10.34172/jhp.2020.20.

\section{Introduction}

Breast cancer triggers the most mortality to women worldwide (1). Indonesia is a country with a high number of breast cancer cases. More than 36 per 100000 of the total population suffer from breast cancer (2). Generally, treatments for breast cancer patients are surgery, radiotherapy, and chemotherapy, but these procedures often lead to resistance resulting in death (3). In addition, breast cancer also affects physiological conditions that worsen the condition of the patient. One of the physiological disorders is oxidative stress in the liver $(4,5)$. Furthermore, certain disease can emerge due to chemotherapy treatment such as cisplatin $(6,7)$.

Oxidative stress in the liver under breast cancer conditions was confirmed by Hojo et al in vivo (8). Although the mechanism is still unresolved, most likely the occurrence of oxidative stress is caused by the body's immune response such as cytokine production during cancer progression. Breast cancer may uprise the levels of proinflammatory cytokines such as tumor necrosis factor- $\alpha$ (TNF- $\alpha)$ and interferon- $\gamma($ IFN- $\gamma)$ in response to the cancer progression $(9,10)$. 
Since the spleen is a key organ in systemic regulation of immunity, its condition represents the activity of immune response in the body (11). A recent study suggested that the levels of splenic TNF- $\alpha$ and IFN- $\gamma$ were augmented in the mice model of breast cancer $(12,13)$. On the other hand, the liver also has many immunocompetent cells, such as Kupffer cells, which can be activated by those cytokines. Activated Kupffer cells can synthesize reactive oxygen species (ROS) and reactive nitrogen species and induce elevation of oxidant levels leading to oxidative stress (14).

Liver is the organ responsible for detoxification and xenobiotic metabolism, so it has the highest risk of experiencing oxidative stress among other organs. To deal with this condition, the liver is adapted by producing several antioxidant proteins such as heme oxygenase (HO) and superoxide dismutase (SOD). Those proteins are regulated by transcription factor $\mathrm{Nrf} 2$, which will be bound to antioxidant responsive element in DNA to transcribe genes for HO and SOD proteins $(15,16)$. Alteration levels of those proteins may represent the presence of oxidative stress in the liver.

Exploration of herbal compounds continues to be developed as a safe alternative medicine to treat breast cancer, including combining several herbal compounds to provide better efficacy (17). One of the results of the herbal compound combination is Cheral, which consists of White Turmeric (Curcuma longa) and Meniran (Phyllanthus niruri). Both C. longa and P. niruri have high antioxidant properties that can either eliminate oxidants directly or regulate signaling such as $\mathrm{Nrf} 2$ and induce $\mathrm{HO}$ and SOD (18-22). In addition, extracts from these or other species of their families have anti-inflammatory and hepatoprotective activities (23-25). Therefore, this study aims to evaluate the hepatoprotective and antiinflammatory properties of Cheral to prevent liver oxidative stress during breast cancer condition in vivo.

\section{Materials and Methods}

Mice and breast cancer model

Female Balb/c mice (24 individuals, 6-8 weeks old) were purchased from the Institute for Research and Community Service (LPPM), Gadjah Mada University, Yogyakarta, Indonesia. After 1 week of acclimatization, mice were injected with 7,12-dimethylbenz[a]anthracene (DMBA) (Tokyo Chemical Industry, Japan) dissolved by corn oil with dose as performed by Jayakumar et al (26) with some modification. In general, DMBA was given at the dose of $0.015 \mathrm{mg} / \mathrm{g}$ subcutaneously in the mammary region once in a week for 6 consecutive weeks. The confirmation of tumor formation was performed by palpation and histological observation.

Experimental design and Cheral treatment

Mice were divided into six groups, i.e. normal (N), breast cancer $(\mathrm{K})$, breast cancer with cisplatin treatment, $3 \mathrm{mg} /$ $\mathrm{kg}$ (CISP) (27), breast cancer with Cheral treatment, $2,466 \mathrm{mg} / \mathrm{kg}$ (D1), breast cancer with Cheral treatment, $1,233 \mathrm{mg} / \mathrm{kg}$ (D2), and breast cancer with Cheral treatment, 4,932 mg/kg (D3). Cisplatin was given through intraperitoneal injection (27), while Cheral was given through oral administration for 14 consecutive days. Having been treated for 14 days, the mice were sectioned for hepatocyte and splenic cells isolation.

Isolation of hepatocyte and splenic cells

The mice were killed by neck dislocation and then dissected for liver and spleen isolation. Liver and spleen then rinsed with sterile phosphate buffer saline (PBS) and homogenized using syringe holder in a petri dish containing PBS. The cell suspension was transferred to the polypropylene tube and PBS was added until $10 \mathrm{~mL}$ volume then they were centrifuged $\left(2500 \mathrm{rpm}, 10^{\circ} \mathrm{C}, 5\right.$ minutes). The supernatant was exiled from pellets then the pelles were resuspended in $1 \mathrm{ml}$ PBS sterile.

\section{$\mathrm{HO}, \mathrm{Nrf} 2, \mathrm{SOD}, \mathrm{TNF}-\alpha$ and IFN- $\gamma$ detection}

A total of $50 \mu \mathrm{L}$ hepatocyte and splenic cell suspensions were divided into $1.5 \mathrm{~mL}$ microtube containing $400 \mu \mathrm{L}$ of PBS, then they were centrifuged $\left(2500 \mathrm{rpm}, 10^{\circ} \mathrm{C}, 5\right.$ minutes). The pellet containing hepatocytes was added with fixation buffer (BioLegend, USA) and incubated for 30 minutes, then the mixture was added with intracellular staining perm wash buffer or wash-perm (BioLegend, USA) before they were centrifuged $\left(2500 \mathrm{rpm}, 10^{\circ} \mathrm{C}\right.$, 5 minutes). The pellet was added the primary antibody (anti-Nrf2, anti-HO, and anti SOD) (BioLegend, USA) and incubated for 30 minutes. Having been incubated, the mixture was rinsed with wash-perm and centrifuged again (2500 rpm, $10^{\circ} \mathrm{C}, 5$ minutes). Then, the pellet portion was added the secondary antibody FITC (BioLegend, USA) and incubated for 20 minutes. After the sample was incubated, it was resuspended with PBS and analyzed using flow cytometer (BD FACSCalibur, USA).

TNF- $\alpha$ and IFN- $\gamma$ levels were analyzed from splenic cells. In general, the pellets containing spleen cells were mixed with extracellular antibodies (BioLegend, USA) and incubated for 30 minutes. After the incubation process completed, the cell suspension was added the fixation buffer (BioLegend, USA) and incubated again for 30 minutes. Then, it was added the wash-perm (BioLegend, USA) and centrifuged ( $2500 \mathrm{rpm}, 10^{\circ} \mathrm{C}, 5$ minutes $)$. The pellet portion was separated from the supernatant and added the anti-TNF- $\alpha$, and IFN- $\gamma$ (BioLegend, USA) then incubated for 20 minutes. After incubation, the cell suspension was resuspended with PBS and analyzed by flow cytometer (BD FACSCalibur, USA).

Data analysis

The result from flow cytometry was analyzed using 
BD Cellquest Pro ${ }^{\mathrm{TM}}$ program. Statistical analysis was performed using one-way ANOVA with $\alpha=5 \%$ followed by Tukey Honestly Significant Difference (HSD) test to evaluate the significant difference among treatments (SPSS, IBM Statistics, USA).

\section{Results}

The hepatoprotective role of Cheral to modulate oxidative stress during carcinogenesis was shown by declining level of HO compared to cancer group $(\mathrm{K})(P<0.05)$. The decrease in HO levels in the treated dose resembles normal healthy group conditions. This was indicated by the absence of the significant difference between the two groups, especially in the treatment of dose 1 (D1). Treatment of dose 1 tended to give a better effect than the cisplatin group, although there was no significant difference between them (Figure 1).

Cheral also had a modulation effect on hepatic oxidative stress as presented in SOD levels. The best dose to modulate SOD was dose 1, strengthened by similarity to normal conditions $(P>0.05)$. The cisplatin group, dose 2 , and dose 3 had similar efficacy in modulating SOD statistically, but Cheral administration was able to give better results than cisplatin. Administration of cisplatin reduced SOD levels, although it was not significant when being compared to the cancer group. On the other hand, oxidative stress was shown in the cancer group with the highest SOD level among other groups $(P<0.05)$ (Figure 2).

The level of Nrf2 was relatively similar in all treatments
$(P>0.05)$. Neither normal, cancer, nor Cheral dose treatment groups had significantly different $\mathrm{Nrf2}$ levels. This result allows the possibility of $\mathrm{HO}$ and SOD regulatory mechanisms without going through the Nrf2 pathway (Figure 3).

TNF- $\alpha$ and IFN- $\gamma$ levels were measured to confirm the protective role of Cheral in reducing oxidative stress in the liver through regulation of spleenic proinflammatory cytokines. As secondary lymphoid organ, spleen condition represents imunological occasions throughout the body. The effect of Cheral administration on TNF- $\alpha$ and IFN- $\gamma$ levels is shown in Figure 4 and Figure 5, respectively. The breast cancer group showed the highest augmentation in TNF- $\alpha$ level among other groups (Figure 4). These results emphasize the role of TNF- $\alpha$ as oxidative stress inducer in mice under breast cancer condition. On the other hand, administration of cisplatin and Cheral can significantly downregulate TNF-a levels as well as normal healthy group. The cisplatin treatment group also showed a decrease in TNF- $\alpha$ levels compared to the cancer group $(P<0.05)$.

Cheral administration caused a similar result to IFN- $\gamma$ as well as TNF- $\alpha$ levels. It was consistent with TNF- $\alpha$, IFN- $\gamma$ levels increasing significantly in the cancer group compared to the normal healthy group. Administration of cisplatin and some doses of Cheral could decrease the levels of IFN $-\gamma$. Significant decrease in IFN- $\gamma$ level occurred in the cisplatin and dose $3(P<0.05)$ groups. In doses 1 and 2 groups, IFN- $\gamma$ levels were also decreased but with less profound when being compared with the cancer
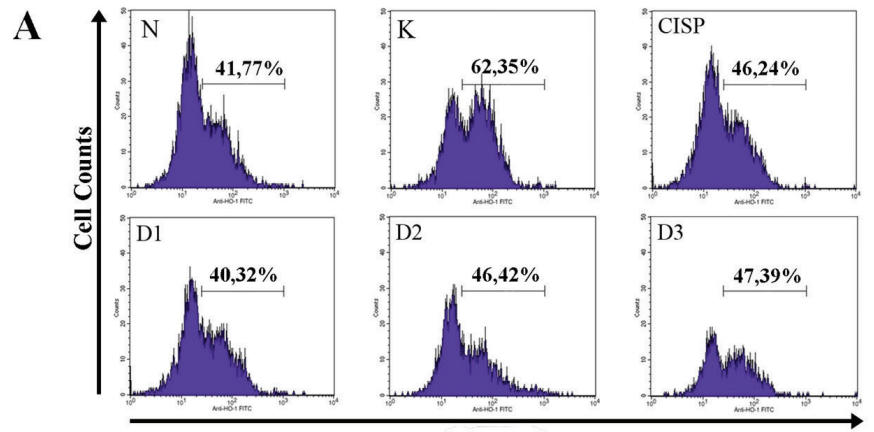

Intensity

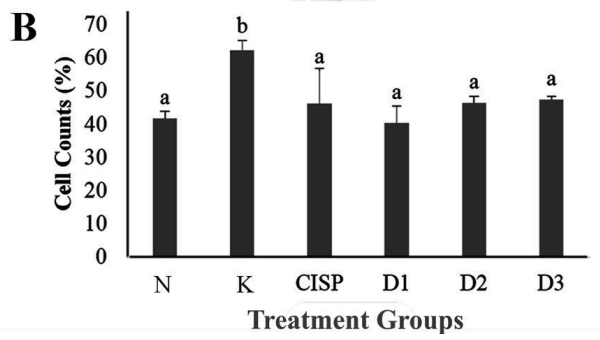

Figure 1. The effect of Cheral treatment on liver-derived Heme Oxigenase $(\mathrm{HO})$ levels compared to normal healthy (N), cancer (K), and Cisplatin group (CISP). Cheral treatment could modulate $\mathrm{HO}$ level as well as normal healthy group compared with cancer group, shown by flow cytometric histogram (A) and statistical analysis (B). N: normal healthy mice, no-treatment; K: breast cancer mice, no-treatment; CISP: breast cancer mice, cisplatin treatment; D1: breast cancer mice, dose 2,466 mg/kg treatment; D2: breast cancer mice, dose 1,233 mg/kg treatment; D3: breast cancer mice, dose 4,932 mg/kg treatment. Results represent mean \pm standart deviation $(S D), n=4$. Different notation shows significant difference among groups based on Tukey HSD test $(P \leq 0.05)$. 

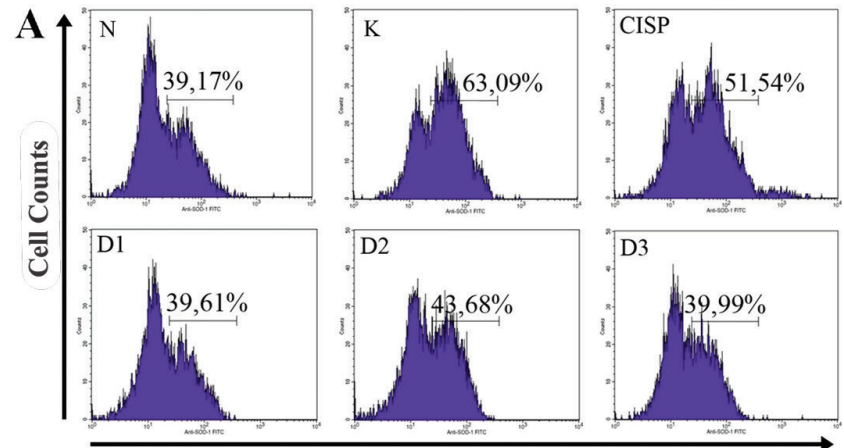

Intensity

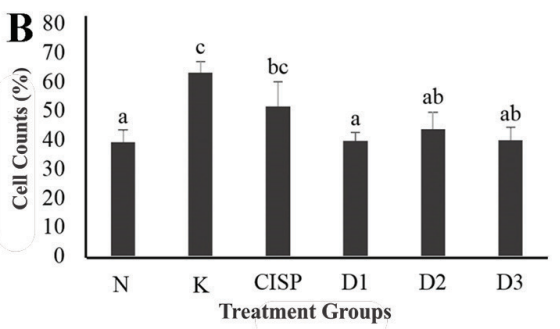

Figure 2. The effect of Cheral treatment on liver-derived Superoxide Dismutase (SOD) levels compared to normal healthy (N), cancer (K), and Cisplatin group (CISP). Cheral can modulate SOD levels better than cisplatin and it also can induce normal-like condition, especially for dose 1 , shown by flow cytometric histogram (A) and statistical analysis (B). N: normal healthy mice, no-treatment; K: breast cancer mice, no-treatment; CISP: breast cancer mice, cisplatin treatment; D1: breast cancer mice, dose 2,466 mg/kg treatment; D2: breast cancer mice, dose 1,233 mg/kg treatment; D3: breast cancer mice, dose $4,932 \mathrm{mg} / \mathrm{kg}$ treatment. Results represent mean $\pm S D, \mathrm{n}=4$. Different notation shows significant difference among groups based on Tukey HSD test $(P \leq 0.05)$.

group (Figure 5). These results pointed out the possibility of the IFN $-\gamma$ role in modulating oxidative stress. At the same time, this data also indicated the potential of Cheral potion in modulating oxidative stress due to breast cancer condition.

\section{Discussion}

There are conditions of oxidative stress in mice model of breast cancer (8) and it is well confirmed in this study by upregulation of $\mathrm{HO}$ and SOD in the cancer group compared with other groups (Figures 1 and 2). High levels of $\mathrm{HO}$
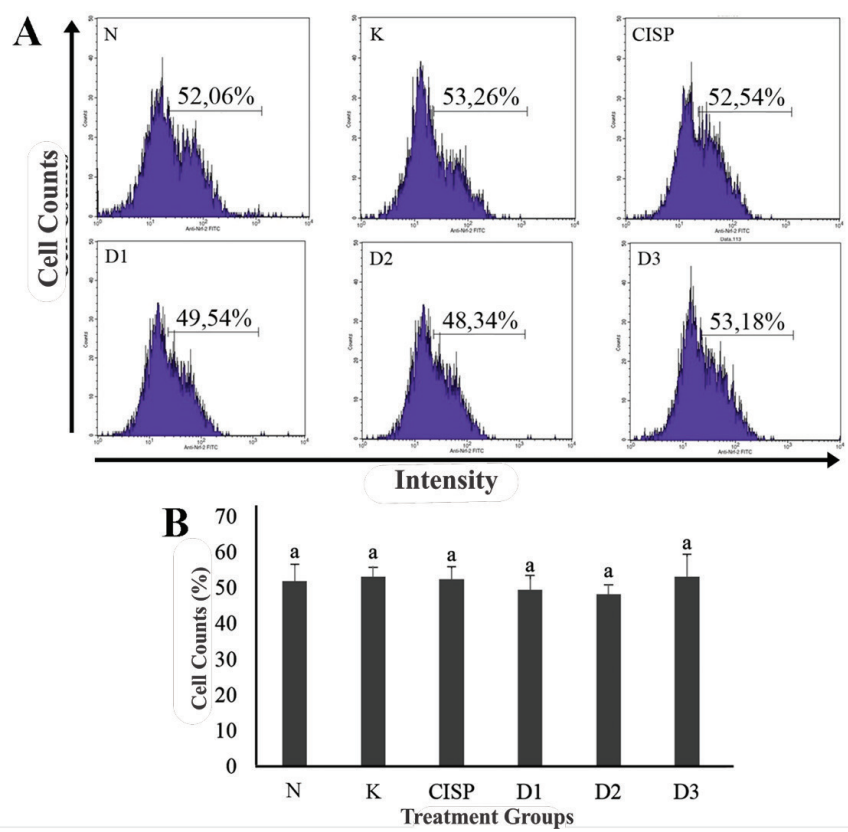

Figure 3. The effect of Cheral treatment on liver-derived Nuclear factor erythroid 2-related factor 2 (Nrf2) levels compared to normal healthy (N), cancer $(\mathrm{K})$, and Cisplatin group (CISP). There is no significant difference for Nrf2 levels among all groups of treatment (A) and based on statistical analysis (B). N: normal healthy mice, no-treatment; K: breast cancer mice, no-treatment; CISP: breast cancer mice, cisplatin treatment; D1: breast cancer mice, dose 2,466 $\mathrm{mg} / \mathrm{kg}$ treatment; D2: breast cancer mice, dose 1,233 mg/kg treatment; D3: breast cancer mice, dose $4,932 \mathrm{mg} / \mathrm{kg}$ treatment. Results represent mean \pm SD, $\mathrm{n}=4$. Different notation shows significant difference among groups based on Tukey HSD test $(P \leq 0.05)$. 


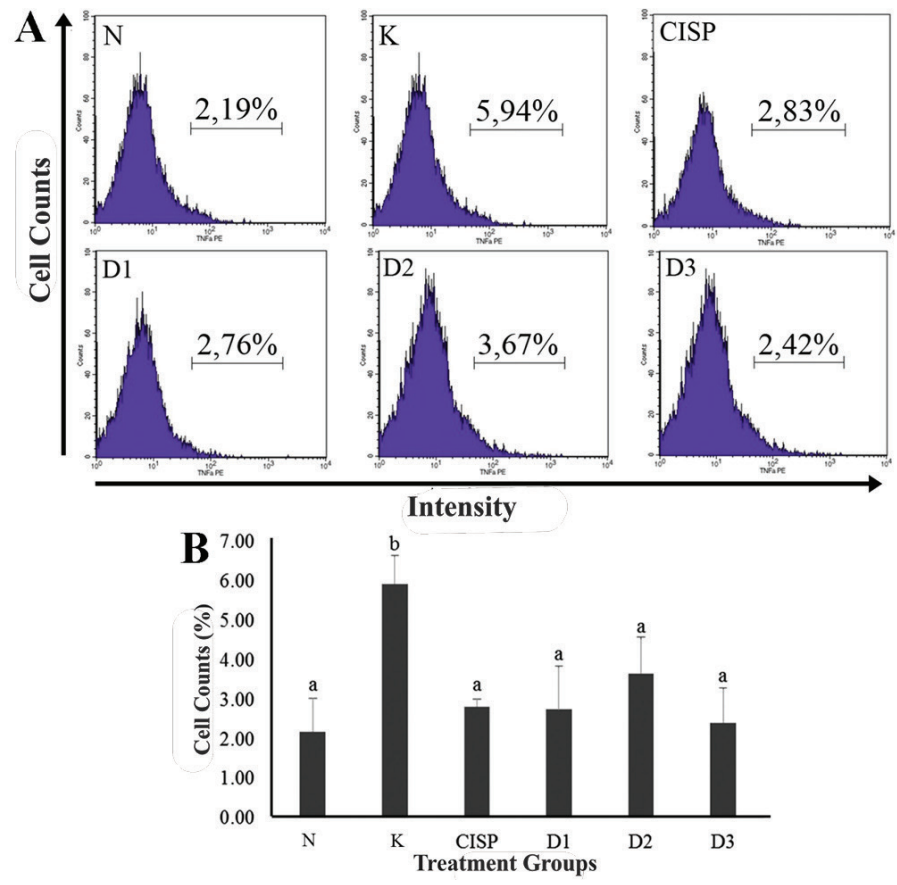

Figure 4. The effect of Cheral treatment on spleen-derived Tumor Necrosis Factor- $\alpha$ (TNF- $\alpha$ ) levels compared to normal healthy (N), cancer (K), and Cisplatin group (CISP). Cheral can downregulate TNF- $\alpha$ to normal-like levels as well as cisplatin (A) and showed statistical difference with cancer group (B). $\mathrm{N}$ : normal healthy mice, no-treatment; K: breast cancer mice, no-treatment; CISP: breast cancer mice, cisplatin treatment; D1: breast cancer mice, dose $2,466 \mathrm{mg} / \mathrm{kg}$ treatment; D2: breast cancer mice, dose 1,233 mg/kg treatment; D3: breast cancer mice, dose 4,932 mg/kg treatment. Results represent mean $\pm \mathrm{SD}, \mathrm{n}=4$. Different notation shows significant difference among groups based on Tukey HSD test $(P \leq 0.05)$.

and SOD are commonly used as indicators for oxidative stress condition in a tissue. Augmentation of $\mathrm{HO}$ level is a mechanism of cellular sensitivity to oxidative stress by producing $\mathrm{HO}$ in large quantities for oxidant elimination (28). In addition, high levels of SOD are also a form of cellular response under oxidative stress, particularly in liver disorders. Liver entering hepatocellular carcinoma pathogenesis also suggests an increase in SOD levels in the early stages (29).

The hepatoprotective effect of Cheral to oxidative stress in this study was shown by decreasing levels of $\mathrm{HO}$ and SOD as well as normal healthy group condition (Figures 1 and 2). Cheral potion has an advantage in modulating oxidative stress due to the combination of various antioxidant compounds in its composition. Antioxidants combinations have better efficacy than one type of antioxidant alone (30). C. longa and P. niruri as the main compositions of Cheral potion contain various types of antioxidants that have been widely evaluated to reduce oxidative stress and treat cancer. C. longa contains phenols, saponins, flavonoids, curcumin, and some polyphenol compounds which are widely proven as good antioxidants $(18,19,22)$. P. niruri contains many phenols, flavonoid, and tannin that also widely proven their antioxidant activities (31).

The antioxidant ability of Cheral was performed through non-enzymatic reaction by alleviating $\mathrm{HO}$ and SOD levels, which can interact directly with oxidants (32).
Flavonoid compounds are capable of forming a complex with copper or iron to prevent ROS formation $(33,34)$. In addition, curcumin from Curcuma species can disrupt the structural stability of free radicals by transferring electrons to $\mathrm{H}$ atoms in $\mathrm{OH}$ and $\mathrm{CH}_{2}$ groups that cause prevention of adverse cellular damage $(35,36)$. When antioxidants from Cheral eliminate free radicals, the tissues will return to homeostasis conditions and the levels of the indigenous antioxidant proteins such as $\mathrm{HO}$ and SOD are reduced (Figures 1 and 2).

There was no significant difference for Nrf2 in all experimental groups (Figure 3) showing that $\mathrm{HO}$ and SOD regulation occurs without going through the Nrf2 pathway. In addition to the Nrf2 transcription factor, $\mathrm{HO}$ can be regulated by Bach-1 repressor transcription factor (37). Bach-1 protein is bound to the promoter region to prevent transcription of the $\mathrm{HO}$ gene (38). This process occurs when intracellular heme level is low (39). On the other hand, polyphenols and flavonoids can scavenge heme and make the intracellular heme reduced $(40,41)$. Low level of heme generates Bach-1 interaction with the promoter region of the $\mathrm{HO}$ to suppress $\mathrm{HO}$ transcription. This mechanism will lead to HO reduction so that the $\mathrm{HO}$ level in the Cheral treatment becomes lower than the cancer group.

High level of SOD implies the presence of oxidative stress in tissue (29). The declining levels of SOD in this study (Figure 2) have a similar result with Schaffer et al 


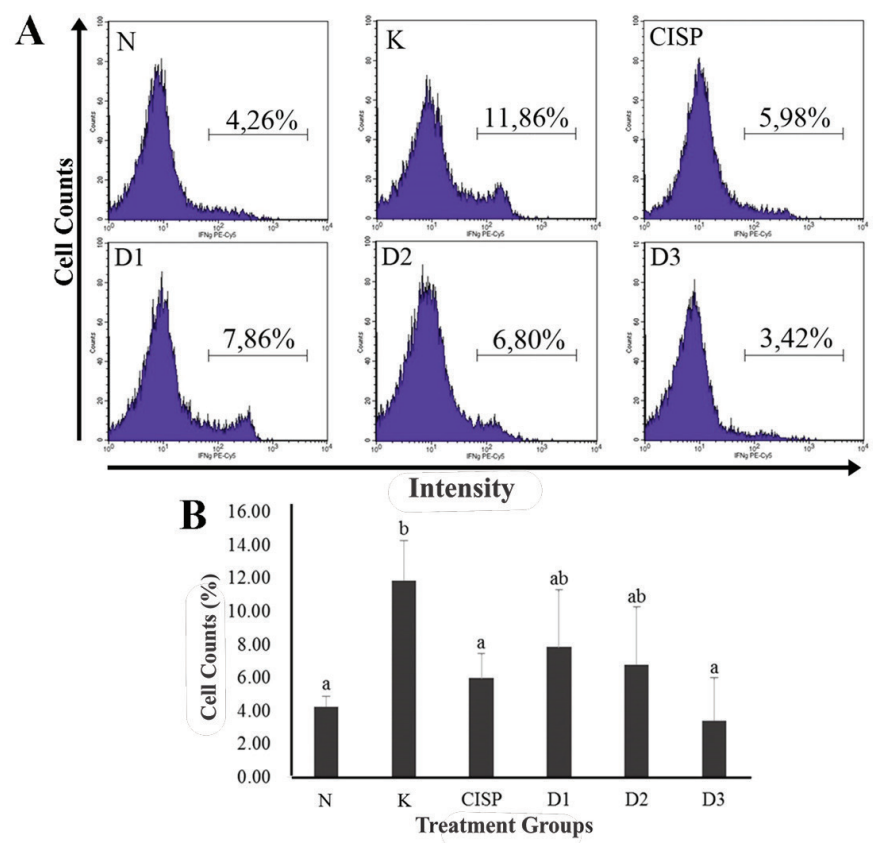

Figure 5. The effect of Cheral treatment on spleen-derived Interferon- $\mathrm{Y}$ (IFN- $\mathrm{Y}$ ) levels compared to normal healthy (N), cancer (K), and Cisplatin group (CISP). IFN-y levels decreased significantly in cisplatin group and dose 3, shown by flow cytometric histogram (A) and based on statistical analysis (B). N: normal healthy mice, no-treatment; K: breast cancer mice, no-treatment; CISP: breast cancer mice, cisplatin treatment; D1: breast cancer mice, dose 2,466 $\mathrm{mg} / \mathrm{kg}$ treatment; D2: breast cancer mice, dose $1,233 \mathrm{mg} / \mathrm{kg}$ treatment; D3: breast cancer mice, dose $4,932 \mathrm{mg} / \mathrm{kg}$ treatment. Results represent mean \pm SD, $\mathrm{n}=4$. Different notation shows significant difference among groups based on Tukey HSD test $(\mathrm{p} \leq 0.05)$. $(P \leq 0.05)$.

(42) study which explains that polyphenols in the extract can act as a radical scavenger. Also, SOD provokes redox balance in the tissues (42). The downregulation of SOD levels in this study might involve the PI3k/Akt pathway and the transcription factor NF- $\mathrm{kB}$ since NF- $\mathrm{kB}$ controls the expression of SOD through the PI3K/Akt mechanism (43). In a previous research, Curcumenol from C. longa and extract from $P$. niruri were able to inhibit the PI3K/ Akt pathway to decrease NF-kB $(16,44)$ and downregulate SOD level.

Breast cancer causes the liver to undergo oxidative stress through the elevation of $\mathrm{HO}$ and SOD levels compared with other groups (Figures 1 and 2). Oxidative stress can be induced by inflammation through the elevation of TNF- $\alpha$ and IFN- $\gamma$ as represented in lymphoid organ conditions such as spleen $(9,10,45)$. Under cancer conditions, immune cells will produce large amounts of TNF- $\alpha$ and IFN- $\gamma$ and spread through blood vessels, lymphatic vessels, and lymphoid organs $(9,10)$. Augmentation of TNF- $\alpha$ and IFN- $\gamma$ can increase immune system activity in the liver and stimulate inflammation $(14,46)$. On the other hand, both $P$. niruri and curcumin from C. longa extract can suppress TNF- $\alpha$ and IFN- $\gamma(24,47,48)$. Thus, the decreasing levels of spleen-derived TNF- $\alpha$ and IFN- $\gamma$ occur as a result of physiological improvement after Cheral administration and reduction in oxidative damage take place under breast cancer condition.

\section{Conclusion}

This study confirmed that mice models for breast cancer undergo oxidative stress in liver organ based on high $\mathrm{HO}$ and SOD levels. On the other hand, increasing concentration of TNF- $\alpha$ and IFN- $\gamma$ in the cancer group signifies the role of the cytokine in modulating oxidative stress under breast cancer condition. Cheral could improve physiological conditions by diminishing $\mathrm{HO}$, SOD, TNF- $\alpha$, and IFN- $\gamma$ levels. Hence, it might be a good candidate as alternative therapeutic agent for breast cancer condition.

\section{Authors' contributions}

FEH performed study and wrote first draft of the manuscript; AS accomplished statistical analysis and literature search; HT carried out literature research and review; MI comprehended the research idea; MR designed the work and revised the manuscript. All authors read and approved publication of the final manuscript.

\section{Conflict of interests}

All authors declare that there is no conflict of interest.

\section{Ethical considerations}

All animals conditions and handling were approved by the Ethical Committee of Brawijaya University (Ethical Clearance No. 925-KEP-UB).

\section{Funding/Support}

This research was funded by Ministry of Research, Technology, and Higher Education of Republic Indonesia (Grant No. 063/ADD/SP2H/LT/DRPM/VIII/2017). 


\section{References}

1. Anderson BO, Jakesz R. Breast cancer issues in developing countries: an overview of the Breast Health Global Initiative. World J Surg. 2008;32(12):2578-85. doi: 10.1007/ s00268-007-9454-z.

2. Ng CH, Pathy NB, Taib NA, Teh YC, Mun KS, Amiruddin $\mathrm{A}$, et al. Comparison of breast cancer in Indonesia and Malaysia--a clinico-pathological study between Dharmais Cancer Centre Jakarta and University Malaya Medical Centre, Kuala Lumpur. Asian Pac J Cancer Prev. 2011;12(11):2943-6.

3. Castrellon AB, Glück S. Chemoprevention of breast cancer. Expert Rev Anticancer Ther. 2008;8(3):443-52. doi: 10.1586/14737140.8.3.443.

4. Shaheen G, Arshad M, Shamim T, Arshad S, Akram M, Yasmeen Z. Effects of breast cancer on physiological and psychological health of patients. Int J Appl Biol Pharm. 2011;2:236-43.

5. McAllister SS, Weinberg RA. The tumour-induced systemic environment as a critical regulator of cancer progression and metastasis. Nat Cell Biol. 2014;16(8):717-27. doi: $10.1038 / \mathrm{ncb} 3015$.

6. Dasari S, Tchounwou PB. Cisplatin in cancer therapy: molecular mechanisms of action. Eur J Pharmacol. 2014;740:364-78. doi: 10.1016/j.ejphar.2014.07.025.

7. Ko JW, Lee IC, Park SH, Moon C, Kang SS, Kim SH, et al. Protective effects of pine bark extract against cisplatininduced hepatotoxicity and oxidative stress in rats. Lab Anim Res. 2014;30(4):174-80. doi: 10.5625/lar.2014.30.4.174.

8. Hojo H, Enya S, Arai M, Suzuki Y, Nojiri T, Kangawa K, et al. Remote reprogramming of hepatic circadian transcriptome by breast cancer. Oncotarget. 2017;8(21):34128-40. doi: 10.18632/oncotarget.16699.

9. Zhou XL, Fan W, Yang G, Yu MX. The clinical significance of PR, ER, NF- kappa B, and TNF- alpha in breast cancer. Dis Markers. 2014;2014:494581. doi: 10.1155/2014/494581.

10. Zhu X, Du L, Feng J, Ling Y, Xu S. Clinicopathological and prognostic significance of serum cytokine levels in breast cancer. Clin Lab. 2014;60(7):1145-51. doi: 10.7754/clin. lab.2013.130738.

11. Bronte V, Pittet MJ. The spleen in local and systemic regulation of immunity. Immunity. 2013;39(5):806-18. doi: 10.1016/j.immuni.2013.10.010.

12. Kano A. Tumor cell secretion of soluble factor(s) for specific immunosuppression. Sci Rep. 2015;5:8913. doi: 10.1038/ srep08913.

13. Zhang S, Shao Q, Shen Z, Su S. Immunomodulatory response of $4 \mathrm{~T} 1$ murine breast cancer model to camellia royal jelly. Biomed Res. 2017;28(3):1223-30.

14. Mosser DM, Edwards JP. Exploring the full spectrum of macrophage activation. Nat Rev Immunol. 2008;8(12):95869. doi: $10.1038 /$ nri2448.

15. Park EY, Rho HM. The transcriptional activation of the human copper/zinc superoxide dismutase gene by 2,3,7,8-tetrachlorodibenzo-p-dioxin through two different regulator sites, the antioxidant responsive element and xenobiotic responsive element. Mol Cell Biochem. 2002;240(1-2):47-55. doi: 10.1023/a:1020600509965.

16. Tang W, Jiang YF, Ponnusamy M, Diallo M. Role of Nrf2 in chronic liver disease. World J Gastroenterol.
2014;20(36):13079-87. doi: 10.3748/wjg.v20.i36.13079.

17. Mahmoud AM, El-Shemy HA. Cytotoxic profiling of some compounds of natural origin against HepG2 liver cancer cell line in-vitro. J Arid Land Stud. 2012;22:191-4.

18. González-Reyes S, Guzmán-Beltrán S, Medina-Campos ON, Pedraza-Chaverri J. Curcumin pretreatment induces Nrf2 and an antioxidant response and prevents hemininduced toxicity in primary cultures of cerebellar granule neurons of rats. Oxid Med Cell Longev. 2013;2013:801418. doi: 10.1155/2013/801418.

19. Park W, Amin AR, Chen ZG, Shin DM. New perspectives of curcumin in cancer prevention. Cancer Prev Res (Phila). 2013;6(5):387-400. doi: 10.1158/1940-6207.capr-12-0410.

20. Bhattacharyya S, Banerjee S, Guha C, Ghosh S, Sil PC. A $35 \mathrm{kDa}$ Phyllanthus niruri protein suppresses indomethacin mediated hepatic impairments: Its role in Hsp70, HO1 , JNKs and $\mathrm{Ca}(2+)$ dependent inflammatory pathways. Food Chem Toxicol. 2017;102:76-92. doi: 10.1016/j. fct.2017.01.028.

21. Chatterjee M, Sil PC. Protective role of Phyllanthus niruri against nimesulide induced hepatic damage. Indian J Clin Biochem. 2007;22(1):109-16. doi: 10.1007/bf02912892.

22. Peng X, Dai C, Liu Q, Li J, Qiu J. Curcumin attenuates on carbon tetrachloride-induced acute liver injury in mice via modulation of the Nrf2/HO-1 and TGF-beta1/ Smad3 pathway. Molecules. 2018;23(1). doi: 10.3390/ molecules23010215.

23. Jurenka JS. Anti-inflammatory properties of curcumin, a major constituent of Curcuma longa: a review of preclinical and clinical research. Altern Med Rev. 2009;14(2):141-53.

24. de Melo MN, Soares LA, Porto CR, de Araújo AA, Almeida M, de Souza TP, et al. Spray-dried extract of Phyllanthus niruri L. reduces mucosal damage in rats with intestinal inflammation. J Pharm Pharmacol. 2015;67(8):1107-18. doi: 10.1111/jphp.12408.

25. Adiga S, Vinay BS, Kamath S, Gaonkar B, Panda A, Mohandas Rao KG, et al. Evaluation of hepatoprotective activity of combination of Phyllanthus niruri and Curcuma longa extracts in wistar rats. Res J Pharm Biol Chem Sci. 2012;3(3):1260-8.

26. Jayakumar JK, Nirmala P, Praveen Kumar BA, Kumar AP. Evaluation of protective effect of myricetin, a bioflavonoid in dimethyl benzanthracene-induced breast cancer in female Wistar rats. South Asian J Cancer. 2014;3(2):107-11. doi: 10.4103/2278-330x.130443.

27. Chen Y, Han F, Cao LH, Li C, Wang JW, Li Q, et al. Doseresponse relationship in cisplatin-treated breast cancer xenografts monitored with dynamic contrast-enhanced ultrasound. BMC Cancer. 2015;15:136. doi: 10.1186/ s12885-015-1170-8.

28. Bauer M, Bauer I. Heme oxygenase-1: redox regulation and role in the hepatic response to oxidative stress. Antioxid Redox Signal. 2002;4(5):749-58. doi: $10.1089 / 152308602760598891$.

29. Moreira AJ, Rodrigues G, Bona S, Cerski CT, Marroni CA, Mauriz JL, et al. Oxidative stress and cell damage in a model of precancerous lesions and advanced hepatocellular carcinoma in rats. Toxicol Rep. 2015;2:333-40. doi: 10.1016/j.toxrep.2014.11.015.

30. Koçyiğit A, Selek Ş. Exogenous antioxidants are double- 
edged swords. Bezmialem Sci. 2016;4(2):70-5. doi: 10.14235/bs.2016.704.

31. Bagalkotkar G, Sagineedu SR, Saad MS, Stanslas J. Phytochemicals from Phyllanthus niruri Linn. and their pharmacological properties: a review. J Pharm Pharmacol. 2006;58(12):1559-70. doi: 10.1211/jpp.58.12.0001.

32. Shahidi F, Zhong Y. Novel antioxidants in food quality preservation and health promotion. Eur J Lipid Sci Technol. 2010;112(9):930-40. doi: 10.1002/ejlt.201000044.

33. de Souza RF, De Giovani WF. Antioxidant properties of complexes of flavonoids with metal ions. Redox Rep. 2004;9(2):97-104. doi: 10.1179/135100004225003897.

34. Torreggiani A, Tamba M, Trinchero A, Bonora S. Copper(II)-Quercetin complexes in aqueous solutions: spectroscopic and kinetic properties. J Mol Struct. 2005;744-747:759-66. doi: 10.1016/j.molstruc.2004.11.081.

35. Ak T, Gülçin I. Antioxidant and radical scavenging properties of curcumin. Chem Biol Interact. 2008;174(1):2737. doi: 10.1016/j.cbi.2008.05.003.

36. Salem M, Rohani S, Gillies ER. Curcumin, a promising anti-cancer therapeutic: a review of its chemical properties, bioactivity and approaches to cancer cell delivery. RSC Adv. 2014;4(21):10815-29. doi: 10.1039/C3RA46396F.

37. Paine A, Eiz-Vesper B, Blasczyk R, Immenschuh S. Signaling to heme oxygenase- 1 and its anti-inflammatory therapeutic potential. Biochem Pharmacol. 2010;80(12):1895-903. doi: 10.1016/j.bcp.2010.07.014.

38. Shan Y, Lambrecht RW, Ghaziani T, Donohue SE, Bonkovsky HL. Role of Bach-1 in regulation of heme oxygenase- 1 in human liver cells: insights from studies with small interfering RNAS. J Biol Chem. 2004;279(50):5176974. doi: 10.1074/jbc.M409463200.

39. Ogawa K, Sun J, Taketani S, Nakajima O, Nishitani C, Sassa $\mathrm{S}$, et al. Heme mediates derepression of Maf recognition element through direct binding to transcription repressor Bach1. EMBO J. 2001;20(11):2835-43. doi: 10.1093/ emboj/20.11.2835.

40. Kitagawa S, Sakamoto H, Tano H. Inhibitory effects of flavonoids on free radical-induced hemolysis and their oxidative effects on hemoglobin. Chem Pharm Bull
(Tokyo). 2004;52(8):999-1001. doi: 10.1248/cpb.52.999.

41. Papuc C, Goran GV, Predescu CN, Nicorescu V, Stefan G. Plant polyphenols as antioxidant and antibacterial agents for shelf-life extension of meat and meat products: classification, structures, sources, and action mechanisms. Compr Rev Food Sci Food Saf. 2017;16(6):1243-68. doi: 10.1111/1541-4337.12298.

42. Schaffer TK, Wohlenberg MF, Medeiros N, Martins JB, Agostini F, Funchal C, et al. Evaluation of antioxidant activity of grapevine leaves extracts (Vitis labrusca) in liver of Wistar rats. An Acad Bras Cienc. 2016;88(1):187-96. doi: 10.1590/0001-3765201620140658.

43. Miao L, St Clair DK. Regulation of superoxide dismutase genes: implications in disease. Free Radic Biol Med. 2009;47(4):344-56. doi: 10.1016/j. freeradbiomed.2009.05.018.

44. Harikrishnan H, Jantan I, Haque MA, Kumolosasi E. Anti-inflammatory effects of Phyllanthus amarus Schum. \& Thonn. through inhibition of NF-kappaB, MAPK, and PI3K-Akt signaling pathways in LPS-induced human macrophages. BMC Complement Altern Med. 2018;18(1):224. doi: 10.1186/s12906-018-2289-3.

45. Cavalcanti YV, Brelaz MC, Neves JK, Ferraz JC, Pereira VR. Role of TNF-alpha, IFN-gamma, and IL-10 in the development of pulmonary tuberculosis. Pulm Med. 2012;2012:745483. doi: 10.1155/2012/745483.

46. Wheelhouse NM, Chan YS, Gillies SE, Caldwell H, Ross JA, Harrison DJ, et al. TNF-alpha induced DNA damage in primary murine hepatocytes. Int J Mol Med. 2003;12(6):889-94.

47. Gautam SC, Gao X, Dulchavsky S. Immunomodulation by curcumin. In: Aggarwal BB, Surh YJ, Shishodia S, eds. The molecular targets and therapeutic uses of curcumin in health and disease. Advances in experimental medicine and biology, vol 595. Boston: Springer; 2007. p. 321-41.

48. Fiala M. Curcumin and omega-3 fatty acids enhance NK cell-induced apoptosis of pancreatic cancer cells but curcumin inhibits interferon-gamma production: benefits of omega-3 with curcumin against cancer. Molecules. 2015;20(2):3020-6. doi: 10.3390/molecules20023020. 